\title{
CLONING OF ANTIBIOTIC-RESISTANCE GENES IN STREPTOMYCES
}

\author{
Takeshi Murakami, Chuhei Nojiri, Hiromi Toyama, Eriko Hayashi, \\ Kazuko Katumata, Hiroyuki Anzai, Yuji Matsuhashi, \\ Yujiro Yamada and Kozo Nagaoka \\ Central Research Laboratories, Meiji Seika Kaisha, Ltd. \\ Morooka-cho, Kohoku-ku, Yokohama, 222, Japan \\ (Received for publication May 20, 1983)
}

\begin{abstract}
Antibiotic-resistance genes were shotgun cloned from antibiotic-producing Streptomyces sp. using pock-forming plasmids (pSF689 and pSF765), as cloning vectors. Streptomyces chartreusis SF1623 and S. lividans 66 were used as host strains.

The ribostamycin (RSM) resistance gene was cloned from S. ribosidificus SF733 DNA (on a $2.3 \mathrm{Md}$ PstI fragment) into both S. chartreusis SF1623 and S. lividans 66, using pSF689 as vector.

Kanamycin (KM), novobiocin (NB), destomycin (DM) and racemomycin (RM) resistance genes were cloned from S. kanamyceticus M1164, S. spheroides M1469, S. rimofaciens M1470 and $S$. lavendulae A249 genomic DNA into S. lividans 66, using pSF765 as vector.

Furthermore two types of KM resistance determinants derived from $S$. kanamyceticus M1164 were cloned using S. lividans 66 , the pSF689 vector.

The RSM resistance gene showed no homology to plasmid pSF733 of S. ribosidificus SF733, but hybridized to PstI or BclI digested total DNA of S. ribosidificus SF733.
\end{abstract}

In Streptomyces, recombinant DNA technology is an important technique for the development of genetic knowlege, increasing the yield of antibiotics, and for potential of producing hybrid antibiotics.

This technology has developed rapidly since the discovery of the Streptomyces coelicolor A3(2) pock-forming plasmid, SCP2*, by HoPwood and his group ${ }^{1)}$. Plasmid transformation in Streptomyces was established by BIBB et al. ${ }^{2)}$ and using plasmids, SCP2* and SLP1.2, the methylenomycin resistance gene was cloned $^{3)}$. Subsequently, Tномpson et al. ${ }^{4,5,6)}$ cloned thiostrepton, neomycin (NM), viomycin and erythromycin resistance genes in S. lividans 66.

We have examined pock-forming plasmids from various antibiotic-producing Streptomyces. Four plasmids, pSF689, pSF765, pSF601 and pSF674, had this ability and have been transferred to other species of Streptomyces ${ }^{7}$. This has enabled us to develop other Streptomyces host-vector systems.

The cloning of resistance genes from antibiotic-producing Streptomyces is important in the study of antibiotic biosynthetic genes ${ }^{8)}$, as well as to provide selective markers for plasmid cloning vectors.

In this study, various antibiotic resistance genes have been cloned from various antibiotic-producing Streptomyces to facilitate the application of recombinant DNA technology to antibiotic-producing Streptomyces having diverse antibiotic-sensitivity.

\footnotetext{
Abbreviations: KM; kanamycin, KMA; kanamycin A, KMB; kanamycin B, DKB; dibekacin (dideoxykanamycin B), GM; gentamicin, LVDM; lividomycin, NB; novobiocin, DM; destomycin, RM; racemomycin, RSM; ribostamycin, AAC; aminoglycoside acetyltransferase, APH; aminoglycoside phosphotransferase, Md; megadalton.
} 


\section{Materials and Methods}

Bacterial Strains

The recipient strains used as hosts for recombinant plasmids were $S$. chartreusis $\mathrm{SF} 1623^{9,10)}$ and S. lividans 66. Antibiotic-producing Streptomycetes used as donor strains were S. ribosidificus SF733, S. kanamyceticus M1164, S. spheroides M1469, S. rimofaciens M1470 and S. lavendulae A249. S. lividans 66 was kindly supplied by Dr. N. D. LomovskayA and Dr. K. F. Chater. Other strains were obtained from the Meiji Seika Kaisha Collection.

Growth Conditions for Chromosomal DNA Preparation

The donor strains were grown in MYG medium ${ }^{7}$ at $28^{\circ} \mathrm{C}$ for 48 hours. Chromosomal DNA was isolated as described by $\mathrm{SMITH}^{12)}$.

Isolation of Plasmid DNA

Plasmid DNA was prepared from S. chartreusis SF1623 as previously described by NoJIRI et al. ${ }^{13)}$ or OKANishi et al. ${ }^{14}$. The method for S. lividans 66 was as described by HANSEN et al. ${ }^{15}$.

\section{Shotgun Cloning}

1) Digestion and Ligation Conditions: Foreign DNA was inserted into the vector as follows: Pst I-digested total DNA of the donor strains was inserted into Pst I site of pSF689 or BclI digested chromosome DNA of the donor strains was inserted into $B c$ lI site of pSF765. Vector $(1.5 \mu \mathrm{g})$ and donor DNA $(6.0 \mu \mathrm{g})$ were mixed and digested at $37^{\circ} \mathrm{C}$ for 2 hours in $100 \mu \mathrm{l}$ of digestion buffer which contained $10 \mathrm{~mm}$ Tris- $\mathrm{HCl}$ ( $\mathrm{pH} 7.4$ ), $6 \mathrm{~mm}$ dithiothreitol, $10 \mathrm{mM} \mathrm{MgCl}_{2}$ and 5 units of endonuclease PstI. In the case of $B c l \mathrm{I}$, incubation was at $50^{\circ} \mathrm{C}$ in the same digestion buffer containing $50 \mathrm{~mm} \mathrm{NaCl}$. The digestion mixture was shaken with an equal amount of phenol saturated with TESH buffer $(0.2 \mathrm{M}$ Tris- $\mathrm{HCl}, \mathrm{pH} 8.0,20 \mathrm{~mm}$ EDTA and $50 \mathrm{~mm} \mathrm{NaCl}$ ). The upper layer was removed and the aqueous phase extracted twice with ethyl ether to remove remaining phenol. $300 \mu \mathrm{l}$ of ethanol was added to the aqueous phase and the mixture stored at $-80^{\circ} \mathrm{C}$ for 2 hours. After centrifugation $(10,000 \times g$, 5 minutes), the pellets were washed once with $500 \mu \mathrm{l}$ of cold ethanol, the pellets were dried under vacuum and dissolved in $40 \mu \mathrm{l}$ of sterilized water. The DNA solution was heated at $70^{\circ} \mathrm{C}$ for 10 minutes, and $5 \mu \mathrm{l}$ of ligation buffer which contained $66 \mathrm{~mm}$ Tris- $\mathrm{HCl}, \mathrm{pH} 7.6,6.6 \mathrm{~mm} \mathrm{MgCl}_{2}, 10 \mathrm{~mm}$ dithiothreitol and $1.0 \mathrm{~mm}$ ATP (each denoting the final concentration) was added and ligation accomplished by incubation with $5 \mu \mathrm{l}$ ( 1 unit) of T4 DNA ligase at $22^{\circ} \mathrm{C}$ for 2 hours.

2) Preparation and Transformation of Protoplasts: Protoplasts were prepared as described by OKANISHI et al. ${ }^{10)}$; transformation of S. lividans 66 was as described by THOMPSON et al. ${ }^{5)}$ or CHATER et al. ${ }^{17)}$. S. chartreusis SF1623 was transformed as described by Toyama et al. ${ }^{10)}$.

3) Selection of Resistance Clones: Transformed protoplasts were regenerated and after spore formation (at $32^{\circ} \mathrm{C}$ for 4 days) the lawns were replicated to plates of BENNETT's medium (S. lividans 66) or YS medium ${ }^{11}$ ) (S. chartreusis SF1623), containing antibiotics at $20 \mu \mathrm{g} / \mathrm{ml}$. After incubation for $2 \sim 3$ days at $32^{\circ} \mathrm{C}$ resistance clones appeared. Resistance clones were picked up, gently homogenized and spread on R2YE medium ${ }^{1,17}$. Spores appearing after incubation at $32^{\circ} \mathrm{C}$ for 4 days were inoculated to YEME medium containing $34 \%$ sucrose and $5 \mathrm{mM} \mathrm{MgCl}_{2}{ }^{1,5,17)}$, and the plasmid was isolated from each culture.

Nick Translation and Southern Hybridization

Nick translation and Southern hybridization with Streptomyces sp. was as described by BiBB et al. ${ }^{37}$. A labelled probe of the $2.3 \mathrm{Md}$ RSM resistance fragment from pMS1 was made by nick translation ${ }^{18)}$ using $\left[\alpha^{3}{ }^{32} \mathrm{P}\right] \mathrm{dCTP}$. This probe was then hybridized to Pst I or BclI-cut total DNA of S. ribosidificus SF733 using the modified method of SOUTHERN ${ }^{19)}$.

Agarose Gel Electrophoresis

Agarose gel electrophoresis was carried out on a horizontal slab gel of $1 \%$ agarose in $\mathrm{E}$ buffer (Tris- $\mathrm{CH}_{3} \mathrm{COOH} 40 \mathrm{~mm}$, EDTA $1 \mathrm{~mm}, \mathrm{CH}_{3} \mathrm{COONa} 5 \mathrm{~mm}, \mathrm{pH}$ 8.0). After electrophoresis for 2 hours at a constant voltage of 100 volts, the bands were visualized by fluorescence under $302 \mathrm{~nm}$ UV light. 


\section{Result}

\section{Shotgun Cloning Experiments}

In the first approach (expt. A), PstI fragments of S. ribosidificus SF733 DNA were ligated into the $P$ st I site of pSF689 vector, and $S$. chartreusis $\mathrm{SF} 1623$ protoplasts were transformed with the ligated

Table 1. Antibiotic resistance clones obtained by shotgun cloning.

\begin{tabular}{|c|c|c|c|c|c|c|c|c|}
\hline \multirow[b]{2}{*}{ Experiment } & \multirow[b]{2}{*}{$\begin{array}{l}\text { Cloning } \\
\text { vector }\end{array}$} & \multirow[b]{2}{*}{$\begin{array}{l}\text { Cloning } \\
\text { site }\end{array}$} & \multirow[b]{2}{*}{$\begin{array}{l}\text { Host } \\
\text { strain }\end{array}$} & \multicolumn{5}{|c|}{ Donor strain } \\
\hline & & & & $\begin{array}{l}\text { S. ribo- } \\
\text { sidificus } \\
\text { SF733 } \\
\text { (RSM)* }\end{array}$ & $\begin{array}{l}\text { S. kana- } \\
\text { myceticus } \\
\text { M1164 } \\
(\mathrm{KM})^{*}\end{array}$ & $\begin{array}{c}S . \\
\text { spheroides } \\
\text { M1469 } \\
\text { (NB)* }\end{array}$ & $\begin{array}{c}S . \\
\text { rimofaciens } \\
\text { M1470 } \\
\text { (DM)* }\end{array}$ & $\begin{array}{c}S . \\
\text { lavendulae } \\
\text { A249 } \\
\text { (RM)* }\end{array}$ \\
\hline Expt. A & pSF689 & Pst $\mathrm{I}$ & $\begin{array}{c}\text { S. chartreusis } \\
\text { SF1623 }\end{array}$ & + & $\mathrm{NT}^{* *}$ & $\mathrm{NT}^{* *}$ & $\mathrm{NT}^{* *}$ & $\mathrm{NT}^{* *}$ \\
\hline Expt. B & pSF689 & Pst $\mathrm{I}$ & S. lividans 66 & + & + & - & - & - \\
\hline Expt. C & pSF765 & $B c l \mathrm{I}$ & S. lividans 66 & - & + & + & + & + \\
\hline
\end{tabular}

* Product.

** Not tested.

Fig. 1. Agarose gel electrophoresis of recombinant plasmids cleaved by restriction enzymes.

A: Pst I digests of plasmid from S. chartreusis SF1623.

1: Hind III digested phage $\lambda$ cI DNA.

2: pMS1 (contains pSF689 and the 2.3 Md RSM resistance fragment).

B: Pst I digests of plasmids from S. lividans 66.

1: Hind III digested phage $\lambda$ cI DNA.

2: pSF689

3: pMS1 (contains pSF689 and the 2.3 Md RSM resistance fragment).

4: pMS19 (contains pSF689 and the 6.0. Md KM resistance fragment I).

5: pMS21 (contains pSF689 and the 5.2 Md KM resistance fragment II).

C: BclI digests of plasmids from $S$. lividans 66.

1: Hind III digested phage $\lambda$ cI DNA.

2: pSF765

3: pMS18 (contains pSF765 and the 1.3 Md KM resistance fragment I).

4: pMS32 (contains pSF765 and the 4.1 Md NB resistance fragment).

5: pMS14 (contains pSF765 and the $2.8 \mathrm{Md}$ DM resistance fragment).

6: pMS33 (contains pSF765 and the $3.5 \mathrm{Md}$ RM resistance fragment).

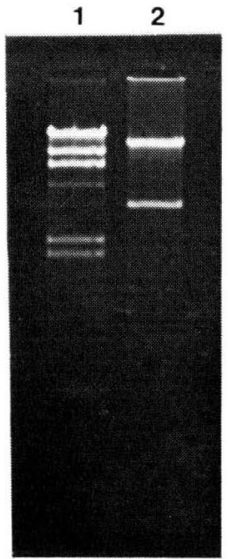

A

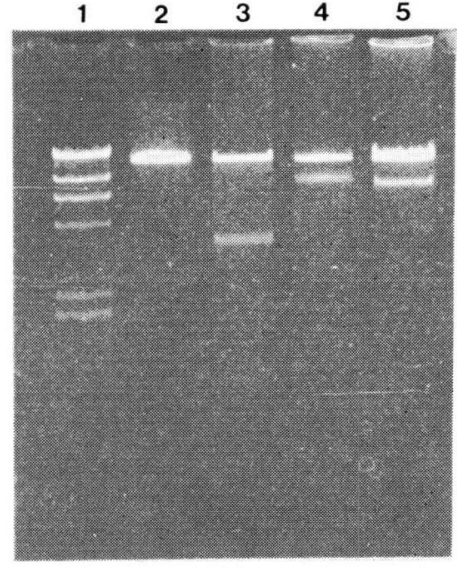

B

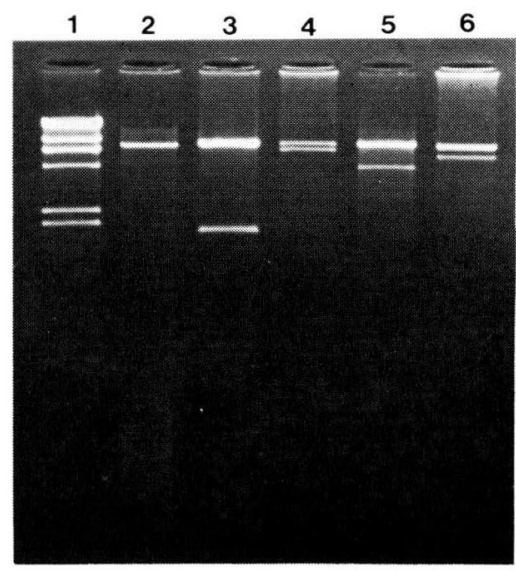

C 
mixture.

In the second (expt. B), PstI fragments of S. ribosidificus SF733, S. kanamyceticus M1164, S. spheroides M1469, S. rimofaciens M1470 and S. lavendulae A249 DNAs were separately ligated into the single Pst I site of the pSF689 vector. S. lividans 66 protoplasts were transformed with each ligated mixture respectively.

In the third (expt. C), $B c l$ I fragments of the above donor strains were ligated into the single $B c / \mathrm{I}$ site of pSF765 and the mixtures used to transform S. lividans 66 protoplasts.

In expt. A, S. chartreusis SF1623 failed to form spores on regeneration medium. In expt. B and expt. C, transformation was detected by the appearance of "pocks" on a lawn of S. lividans 66 growth arising from the regenerated protoplast population on R2YE medium.

When the lawns were replicated to plates, RSM resistance clones appeared in expt. A and expt. B, KM resistance clones in expt. B and expt. C, NB, DM and RM resistance clones in expt. C respectively (Table 1).

Recombinant plasmids prepared from transformants could re-transform S. lividans 66 protoplasts and resistance clones appeared coincidently with pock-forming clones.

\section{Electrophoretic Analysis of Recombinant Plasmids}

A 2.3 Md Pst I fragment was obtained from the plasmid (pMS1) of RSM resistant S. chartreusis SF1623 (Fig. 1A).

Pst I digests of plasmids (pMS1, pMS19 and pMS21) recovered from RSM and KM resistant transformants of $S$. lividans 66 were analyzed by agarose gel electrophoresis. The RSM resistance gene in this case was also encoded by the $2.3 \mathrm{Md}$ fragment. The KM resistance genes were coded on either the $6.0 \mathrm{Md}$ or $5.2 \mathrm{Md}$ fragments (Fig. 1B).

$B c /$ I digests of plasmids (pMS18, pMS32, pMS14 and pMS33) obtained from KM, NB, DM and RM resistant transformants of $S$. lividans 66 were also analyzed. The KM resistance gene was encoded by a $1.3 \mathrm{Md}$ fragment, the NB resistance gene by a $4.1 \mathrm{Md}$ fragment, the $\mathrm{DM}$ resistance gene by a $2.8 \mathrm{Md}$ fragment and the $\mathrm{RM}$ resistance gene by a $3.5 \mathrm{Md}$ fragment (Fig. 1C).

The $6.0 \mathrm{Md}$ and $5.2 \mathrm{Md} \mathrm{KM}$ resistance fragments were extracted, cigested with $\mathrm{Bcll}$ and re-electrophoresed. The digestion patterns of the two fragments were distinct. The $6.0 \mathrm{Md}$ fragment contained the $1.3 \mathrm{Md} \mathrm{BclI}$ fragment (Fig. 2). The $1.3 \mathrm{Md}$ fragments from pMS18 and pMS19 (contains pSF689 and the $6.0 \mathrm{Md}$ $\mathrm{KM}$ resistance fragment I) were identical and conferred similar resistance spectra in cloning vectors.

Fig. 2. Agarose gel electrophoresis of two different $\mathrm{KM}$ resistance fragments and pMS18, digested with BclI.

1: Hind III digested phage $\lambda$ cI DNA. 2: KM resistance fragment $(6.0 \mathrm{Md})$ from pMS19, produced by $P$ st $\mathrm{I}$. 3: KM resistance fragment $(5.2 \mathrm{Md})$ from pMS21, produced by Pst I. 4: pMS18 (contains pSF765 and the 1.3 Md KM resistance fragment I).

The arrow indicates the $0.46 \mathrm{Md}$ fragment.

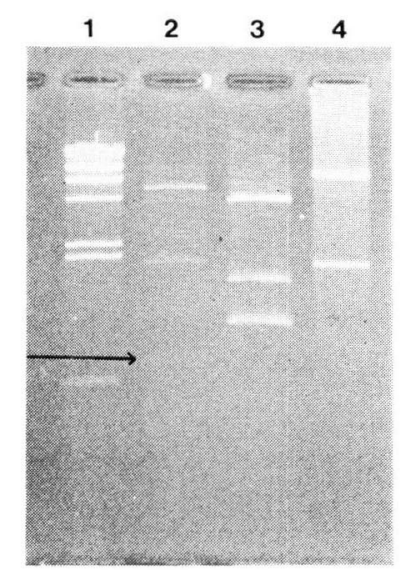


Table 2. MCG* of S. chartreusis SF 1623 and S. lividans 66 harboring antibiotic-resistance gene.

\begin{tabular}{|c|c|c|c|c|c|c|c|c|}
\hline \multirow[t]{2}{*}{$\begin{array}{l}\text { Plasmid } \\
\text { name }\end{array}$} & \multirow[t]{2}{*}{$\begin{array}{l}\text { Resistance } \\
\text { gene }\end{array}$} & \multirow[t]{2}{*}{$\begin{array}{l}\text { Cloning } \\
\text { vector }\end{array}$} & \multirow[t]{2}{*}{$\begin{array}{c}\text { Cloning } \\
\text { site }\end{array}$} & \multirow[t]{2}{*}{$\begin{array}{l}\text { Fragment } \\
\text { size (Md) }\end{array}$} & \multicolumn{2}{|c|}{$\begin{array}{l}\mathrm{MCG}^{*} \text { of } \\
\text { S. chartreusis } \\
\text { Plasmid }\end{array}$} & \multicolumn{2}{|c|}{$\begin{array}{l}\mathrm{MCG}^{*} \text { of } \\
\text { S. lividans } \\
\text { Plasmid }\end{array}$} \\
\hline & & & & & & $(-)$ & $(+)$ & $(-)$ \\
\hline pMS1 & RSM & pSF689 & Pst $\mathrm{I}$ & 2.3 & 1,000 & 5 & 1,500 & 10 \\
\hline pMS18 & KM-I & pSF765 & $B c l$ I & 1.3 & & & 100 & 2.5 \\
\hline pMS21 & KM-II & pSF689 & Pst $\mathrm{I}$ & 5.2 & & & 250 & 2.5 \\
\hline pMS32 & NB & pSF765 & $B c l I$ & 4.1 & & & 50 & 10 \\
\hline pMS14 & DM & pSF765 & $B c l$ I & 2.8 & & & 500 & 5 \\
\hline pMS33 & $\mathrm{RM}$ & pSF765 & $B c l$ I & 3.5 & & & 1,000 & 5 \\
\hline
\end{tabular}

* Maximum concentration permitting growth, $\mu \mathrm{g} / \mathrm{ml}$.

Table 3. MIC* of S. lividans 66 transformant by pMS plasmids.

\begin{tabular}{lccrrrrr}
\hline Plasmid & KMA & KMB & DKB & GM & RSM & NM & LVDM \\
\hline pMS1 & 2.5 & 2.5 & 5 & 5 & $>80$ & 40 & 20 \\
pMS18 & $>80$ & 40 & $>80$ & 5 & $>80$ & 20 & 20 \\
pMS21 & $>80$ & $>80$ & $>80$ & $>80$ & 10 & 2.5 & 20 \\
none & 2.5 & 2.5 & 5 & 5 & 10 & 2.5 & 20 \\
\hline
\end{tabular}

* $\mu \mathrm{g} / \mathrm{ml}$.

\section{Antibiotic-resistance of Transformants}

The cloned antibiotic-resistance genes (fragment sizes summarized in Table 2) were transformed into S. chartreusis SF1623 and S. lividans 66.

The resistance level of each transformant was indicated by the maximum concentration permitting growth (MCG). As shown in Table 2, the values of the MCG increased in all transformants, for example, with RSM and RM, 100 fold and for NB, 5 fold. The KM resistance gene I and KM resistance gene II differed not only in size of the fragment, but also in their MCG to $\mathrm{KM}, 100 \mu \mathrm{g} / \mathrm{ml}$ and $250 \mu \mathrm{g} / \mathrm{ml}$, respectively.

Fig. 3. Southern hybridization of ${ }^{32} \mathrm{P}$-labelled RSM resistance gene obtained from pMSI to total DNA preparation from $S$. ribosidificus SF733.

Agarose gel electrophoresis patterns (A) and corresponding autoradiograms (B).

1: pSF733 DNA. 2: BclI digested total DNA. 3: Pst I digested total DNA. 4: Hind III digested $\lambda$ CI DNA.

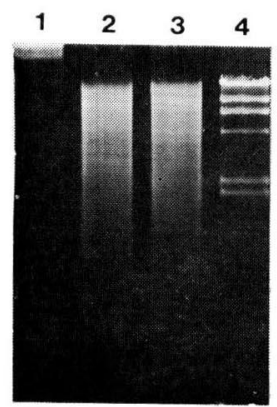

A

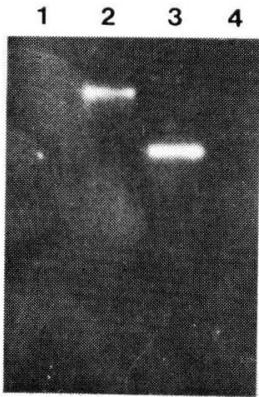

B
S. lividans 66 was transformed by pMS1, pMS18 or pMS21; resistance to the aminoglycoside antibiotics are shown in Table 3. S. lividans 66 harboring pMS1 was resistant to RSM and NM; when harboring pMS18 was resistant to many aminoglycoside antibiotics, except GM and LVDM; pMS21 encoded resistance to the hexose-type aminoglycosides (KM, DKB and GM), but not to the pentose-type aminoglycosides (RSM, NM and LVDM).

Fig. 4. Restriction map of RSM resistance fragment of $S$. ribosidificus $\mathrm{SF733}$.

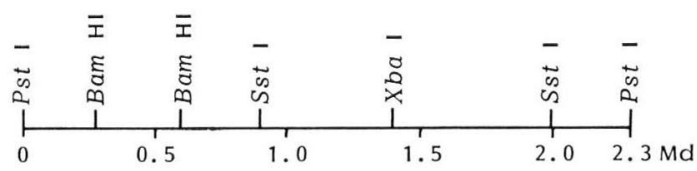


Origin of the RSM Resistance Gene

To determine whether the RSM resistance gene was coded on the chromosome or the pSF733 plasmid $^{13)}$ of S. ribosidificus SF733, a ${ }^{32}$ P-labelled probe of the RSM resistance fragment obtained from pMS1 was made by nick translation and hybridized to Pst I or BclI-cut S. ribosidificus SF733 or pSF733 plasmid DNA. The RSM resistance fragment showed homology to fragments of S. ribosidificus SF733, but not to pSF733 plasmid DNA. In the case of BclI-digested chromosomal DNA, the labelled probe hybridized to a fragment of about $10 \mathrm{Md}$, in case of $P s t \mathrm{I}$ digested chromosomal DNA, to the fragment of $2.3 \mathrm{Md}$.

Cleavage Map of RSM Resistance Gene

A restriction endonuclease cleavage map of the RSM resistance gene of $S$. ribosidificus SF733 is shown in Fig. 4.

\section{Discussion}

Interspecific shotgun cloning of antibiotic resistance genes in Streptomyces has been described by BIBв et al. ${ }^{3)}$ and ThOMPSON et al. ${ }^{4,5)}$ using SCP2* or SLP1.2 as vectors.

We described the use of the pock-forming plasmids pSF689 and pSF765 as vectors for interspecific shotgun cloning in Streptomyces; both S. lividans 66 and S. chartreusis SF1623 could be used as hosts possessing good protoplast formation and regeneration properties and weak restriction systems ${ }^{10,11)}$.

We have suggested previously that the RSM resistance gene was not coded on the plasmid pSF733 ${ }^{13)}$. With the cloning of the gene described here, DNA hybridization experiments indicate that the RSM resistance gene is coded by the chromosome of $S$. ribosidificus SF733.

The RSM resistance gene encodes an RSM phosphotransferase $(\mathrm{APH})^{20)}$ (in preparation), different from the NM resistance gene (APH) cloned from $S$. fradiae ATCC 10745 by THOMPSON et al. ${ }^{4}$, since radioactively labelled 2.3 Md RSM fragment probe failed to hybridize to $B c l$ I or Pst I digests of total DNA of $S$. fradiae ATCC 10745 (data not shown). As confirmation of this, the restriction cleavage map of the RSM resistance gene (Fig. 4) was different from that of the NM resistance gene reported by THOMPSON et al. ${ }^{6)}$.

$S$. ribosidificus SF733 accumulated 3- $N$-acetyl RSM in culture ${ }^{21}$, and the presence of an RSM acetyltransferase activity has been reported ${ }^{20,22)}$. We have confirmed the presence of RSM acetyltransferase in $S$. ribosidificus SF733 by the $\left[{ }^{14}\right.$ C]acetyl CoA transfer studies, however we have so far been not successful in our attempts to clone the RSM acetyltransferase gene.

DNA hybridization studies revealed that the $\mathrm{Bcl}$ I fragment hybridized with the RSM resistance gene was large (about $10 \mathrm{Md}$ ); this may be the reason why this fragment was not cloned in expt. C; in spite of the fact that the $2.3 \mathrm{Md}$ RSM resistance gene had no $\mathrm{Bcll}$ site.

It has been shown that $\mathrm{AAC}\left(6^{\prime}\right)$ is coded on the $1.3 \mathrm{Md}$ fragment of pMS18 containing the $\mathrm{KM}$ resistance gene I cloned from $S$. kanamyceticus M1164 (in preparation), however the resistance mechanism encoded by the 5.2 Md KM resistance fragment II of pMS21 has not been elucidated.

S. lividans 66 harboring pMS18 is sensitive to GM but resistant to RSM. On the other hand S. lividans 66 harboring pMS21 is resistant to GM but sensitive to RSM. This confirms that two independent KM resistance genes are present in $S$. kanamyceticus M1164. It has been reported that $\mathrm{AAC}\left(6^{\prime}\right)$ is involved in the biosynthesis of $\mathrm{KM}^{22)}$.

We have expanded our survey of pock-forming plasmids to various antibiotic-producing Streptomyces using $S$. lividans 66 as indicator strain ${ }^{7}$. However since most high-yielding antibiotic-producing strains are unable to form spores, the pock-forming phenotype is not universally applicable as a genetic and phenotypic marker.

Using cloned antibiotic resistance genes as genetic markers we have examined the host range of several Streptomycetes plasmids and found that the small recombinant plasmid pMS18 had a broad host range. It has been transferred to $S$. chartreusis SF1623 (cephamycin producer), S. griseus (strep- 
tomycin), S. ribosidificus (ribostamycin), S. hygroscopicus SF619 (paromomycin), S. wedmorensis (fosfomycin) by protoplast transformation, and is maintained by the expression of KM resistance.

\section{Acknowledgments}

We thank Dr. S. HosHiko for fruitful discussions and critical reading of the manuscript.

\section{References}

1 Bibb, M. J.; R. F. Freeman \& D. A. Hopwood: Physical and genetical characterisation of a second sex factor, SCP2, for Streptomyces coelicolor A3(2). Mol. Gen. Genet. 154: 155 166, 1977

2) BibB, M. J.; J. M. WARD \& D. A. Hopwood: Transformation of plasmid DNA into Streptomyces at high frequency. Nature 274: 398 400, 1978

3) Bibb, M. J.; J. L. Schottel \& S. N. Cohen: A DNA cloning system for interspecies gene transfer in antibiotic-producing Streptomyces. Nature 284: 526 531, 1980

4) Thompson, C. J.; J. M. WARD \& D. A. Hopwood: DNA cloning in Streptomyces: Resistance genes from antibiotic-producing species. Nature 286: 525 527, 1980

5) Thompson, C. J.; J. M. WARD \& D. A. Hopwood: Cloning of antibiotic resistance and nutritional genes in Streptomyces. J. Bacteriol. 151: 668 677, 1982

6) Thompson, C. J.; T. Kieser, J. M. Ward \& D. A. Hopwood: Physical analysis of antibiotic-resistance genes from Streptomyces and their use in vector construction. Gene 20:51 62, 1982

7) Murakami, T.; C. Nojiri, H. Toyama, E. Hayashi, Y. Yamada \& K. Nagaoka: Pock forming plasmids from antibiotic-producing Streptomyces. J. Antibiotics 36: 429 434, 1983

8) Davis, J.: Enzymes modifying aminocyclitol antibiotics and their roles in resistance determination and biosynthesis. In Aminocyclitol Antibiotics. pp. 323 334, American Chem. Soc., Washington, D.C., 1980

9) Inouye, S.; M. Kojima, T. Shomura, K. Iwamatsu, T. Niwa, Y. Kondo, T. Niida, Y. Ogawa \& K. Kusama: Discovery, isolation and structure of novel cephamycins of Streptomyces chartreusis. J. Antibiotics 36: $115 \sim 124,1983$

10) Toyama, H.; E. HayAshi, K. NAGaOKa \& Y. YAmada: Protoplast-transfection of Streptomyces chartreusis SF1623 with Actinophage ør5 DNA. Agric. Biol. Chem. 47: 1859 1864, 1983

11) Toyama, H.; E. Hayashi, S. Hoshiko, K. Nagaoka \& Y. Yamada: Isolation and characterization of new virulent Actinophage ør5. Agric. Biol. Chem. 47: 1853 1858, 1983

12) Sмітн, M. G.: Isolation of high molecular weight DNA from normal and phage-infected Escherichia coli. Methods in Enzymology 13: 545 550, 1967

13) Nojiri, C.; H. Watabe, K. Katsumata, Y. Yamada, T. Murakami \& Y. Kumata: Isolation and characterization of plasmids from parent and variant strains of Streptomyces ribosidificus. J. Antibiotics 33: $118 \sim 211,1980$

14) Okanishi, M.; T. Manome \& H. UmeZawa: Isolation and characterization of plasmid DNAs in Actinomycetes. J. Antibiotics 33: 88 91, 1980

15) HANSEN, J. B. \& R. H. OlsEn: Isolation of large bacterial plasmids and characterization of the P2 incompatibility group plasmids pMG1 and pMG5. J. Bacteriol. 135: 227 238, 1978

16) OKAnishi, M.; K. Suzuki \& H. UmeZawa: Formation and reversion of Streptomyces protoplast: Cultural condition and morphological study. J. Gen. Microbiol. 80: 389 400, 1974

17) Chater, K. F.; D. A. Hopwood, T. Kieser \& C. J. Thompson: Gene cloning in Streptomyces. Curr. Topics. Microbiol. Immunol. 96: 69 95, 1981

18) Rigby, P. W. J.; M. Dieckman, C. Rhodes \& P. Berg: Labeling deoxyribonucleic acid to high specific activity in vitro by nick translation with DNA polymerase I. J. Mol. Biol. 113: 237 251, 1977

19) Southern, E. M.: Detection of specific sequences among DNA fragments separated by gel electrophoresis. J. Mol. Biol. 98: 503 517, 1975

20) Dowding, J. E.: A fifth class of aminoglycoside 3-phosphotransferase from antibiotic-producing strains of Streptomyces. FEMS Microbiol. Lett. 6: 95 98, 1979

21) Kojima, M.; N. EZAKI, S. Amano, S. InouYe \& T. NiIDA: Bioconversion of ribostamycin (SF-733). II. Isolation and structure of 3- $N$-acetylribostamycin, a microbiologically inactive product of ribostamycin produced by Streptomyces ribosidificus. J. Antibiotics 28: 42 47, 1975

22) Satoh, A.; H. OgaWA \& Y. Satomura: Effect of sclerin on production of the aminoglycoside antibiotics accompanied by salvage function in Streptomyces. Agric. Biol. Chem. 39: 1593 1598, 1975 